\title{
MODEL KOMUNIKASI PADA PROGRAM CSR PEMBERDAYAAN WIRAUSAHA MUDA PERUSAHAAN MIGAS
}

\author{
Saipullah Hasan \\ Dosen Pengembangan Masyarakat Islam IAIN Salatiga \\ saifulhasan@iainsalatiga.ac.id
}

\begin{abstract}
s
The company's effort in carrying out social responsibility is often challenged by social problems including a gap between the quality of regional human resources and the company workforce. In particular, the challenge faced by Exxon Mobil is the gap between the education level of regional human resources, especially among the local youth and the educational qualifications demanded by Exxon Mobil. In responding to the communities' demand, Exxon Mobil realizes the importance of communication to roll out CSR programs in providing information, service and business access to develop new young entrepreneurs. This study aims to analyse the way the company conducted the communication model towards the community empowerment. This study used a qualitative method with a descriptive approach. The results of the study showed that the participatory communication model which is conducted by the company has played important role in achieving the objectives of young entrepreneurs' empowerment as their career choice.
\end{abstract}

Keywords: communication, empowerment, CSR programs, young entrepreneurs.

\begin{abstract}
Abstrak
Upaya perusahaan untuk menjalankan tanggung jawab sosial sering kali terkendala oleh masalah sosial berupa kesenjangan antara kualitas SDM setempat dengan tuntutan kerja perusahaan. Secara lebih spesifik, kendala yang dihadapi perusahaan Exxon Mobil adalah jauhnya kesenjangan antara tingkat pendidikan SDM masyarakat lokal terutama kalangan pemudanya setempat dengan kualifikasi pendidikan yang dituntut oleh Exxon Mobil. Untuk tetap merespons tuntutan masyarakat, Exxon Mobil menyadari pentingnya komunikasi untuk menggulirkan program CSR yang bertujuan memberikan informasi, pelayanan dan akses bisnis untuk membidani kelahiran para wirausaha muda. Penelitian ini bertujuan menganalisis bagaimana model komunikasi yang dilakukan perusahaan untuk memberdayakan masyarakat. Penelitian ini menggunakan metode kualitatif dengan pendekatan deskriptif. Hasil penelitian menunjukkan bahwa model komunikasi partisipatif yang dilakukan perusahaan memainkan peranan penting dalam mencapai tujuan pemberdayaan wirausaha muda sebagai pilihan karir mereka.
\end{abstract}

Kata Kunci: komunikasi, pemberdayaan, program CSR, wirausaha muda. 


\section{Pendahuluan}

Corporate Social Responsibility (CSR) atau tanggung jawab sosial perusahaan di dunia dan di Indonesia kini telah menjadi isu penting berkaitan dengan masalah dampak lingkungan dalam pembangunan berkelanjutan (Porwanto, 2010:16). Isu tentang CSR mulai muncul pada dekade 1950-an. Tepatnya isu tanggung jawab sosial dalam dunia usaha ini pertama kali digunakan oleh Howard R. Bowen di dalam bukunya yang berjudul Social Responsibilities of the Businessman (1953). Menurut Bowen (1953:6) tanggung jawab sosial pelaku bisnis dalam membuat keputusan, menjalankan kebijakan dan melakukan tindakan diharapkan dapat menyesuaikan dengan tujuan dan nilai sosial yang dianut masyarakat. Dengan menjalankan bisnis sesuai tujuan dan nilai sosial, suatu perusahaan akan mudah menyesuaikan dengan lingkungan sekitarnya sehingga mudah pula diterima oleh masyarakat.

Hadirnya perusahaan di lingkungan masyarakat niscaya membawa dampak, baik yang menguntungkan ataupun yang merugikan. Hal-hal menguntungkan yang dibawa oleh perusahaan misalnya adalah bertambahnya pemasukan pemerintah melalui pajak, pembukaan lapangan kerja baru, terpicunya aktivitas perekonomian lokal, dan banyak lagi lainnya. Adapun kerugian-kerugian atau dampak negatif yang sering ditimbulkan oleh perusahaan antara lain pencemaran lingkungan, penggerusan sumber daya alam, marginalisasi sebagian masyarakat yang tidak memiliki akses ke dalam industrialisasi, dan berbagai akibat negatif lain (Hasan dan Andriani, 1:2014).

Dampak negatif yang ditimbulkan masing-masing perusahaan memiliki tingkat permasalahan yang berbeda-beda sesuai dengan karakter industrinya. Data BP Migas (2010), menyebutkan bahwa menurut statistik selama 10 tahun (2000-2010), sekitar 50\% kegiatan eksplorasi hulu migas tidak dapat direalisasikan karena terbentur berbagai masalah sosial, misalnya kurangnya pemahaman masyarakat (Kompas,17 Juli 
2012). Fenomena inilah yang menjadi dasar diperlukannya komunikasi program CSR tentang pemahaman tanggung jawab sosial perusahaan untuk memberdayakan masyarakat setempat.

Hambatan dan masalah sosial yang dihadapi perusahaan migas tidak diimbangi dengan keberadaan departemen CSR. Banyak dari mereka yang tidak memiliki departemen khusus yang mengelola program CSR. Perencanaan, implementasi dan evaluasi hanya menjadi additional job pada jabatan tertentu, misalnya Humas (Bahruddin, 2012:117). Faktorfaktor gangguan sosial seharusnya menjadi dasar dalam pengelolaan program CSR. Kajian ilmu komunikasi dan community development sudah saatnya bergandengan dalam mengelola bisnis yang berkelanjutan dan bermanfaat bagi masyarakat setempat.

Dalam perkembangannya manajemen komunikasi dalam kalangan bisnis tidak hanya terbatas sebagai corong perusahaan, tuntutan peran dan fungsi public relation semakin meluas untuk berperan sebagai community development diantaranya: (1) Memahami dan mengerti bagaimana harusnya menyikapi keadaan komunitas yang semakin kritis terhadap parktik bisnis. (2) Bagaimana harusnya menyikapi ketimpangan sosial ekonomi antara kehidupan dalam industri yang bersinggungan dengan kondisi objektif di komunitas lingkungan perusahaan yang jauh berbeda. (3) Bagaimana membangun hubungan yang baik dengan komunitas di mana perusahaan itu berada sebagai bagian dari kehidupan bermasyarakat, berbangsa dan bernegara.

Di Indonesia, pentingnya program community development dengan prinsip pemberdayaan tercantum di dalam Undang-undang No. 22 Tahun 2001 tentang Perusahaan Minyak dan Gas Bumi. Berdasarkan undangundang tersebut, perusahaan yang operasinya terkait dengan migas baik sebagai pengelola eksplorasi maupun distribusi wajib melaksanakan kegiatan pengembangan masyarakat dan menjamin hak-hak masyarakat adat yang berada di sekitar perusahaan. Undang-undang Migas tersebut mendorong komitmen perusahaan untuk fokus pada program pengem- 
bangan atau pemberdayaan masyarakat. Menurut Scots (dalam Muthuri dan Gilbert, 2010:4) tekanan regulasi akan menumbuhkan lingkungan yang kondusif untuk penerapan CSR baik dalam hal fokus sasaran maupun bentuknya. Selanjutnya, menurut Robert Reich, hukum adalah satu-satunya alat yang memungkinkan untuk mendorong korporasi agar menjalankan tanggung jawab sosialnya (Shaw, 2009:570).

Exxon Mobil merupakan korporasi yang bergerak di bidang minyak dan gas bumi (migas) yang wilayah operasinya berada di Blok Cepu Bojonegoro. Sebagai korporasi industri migas, Exxon Mobil hendaknya menyadari bahwa segala aktivitas yang dilakukan perusahaan pasti akan membawa dampak secara langsung bagi lingkungan alam maupun sosial di sekitarnya. Sementara pada sisi lain, ada tuntutan di masyarakat bahwa sebuah perusahaan haruslah bertanggung jawab atas berbagai dampak dari beroperasinya perusahaan tersebut.

Dalam skala global Exxon Mobil menjadi perusahaan terbesar di dunia dalam bidang energi terus-menerus di bawah tekanan sosial. Secara lebih spesifik persoalan yang dihadapi adalah adanya pengangguran dan ketergantungan masyarakat lokal terutama kalangan pemuda untuk bekerja di proyek migas. Ketika jangka waktu proyek habis mereka menjadi pengangguran dan menunggu sampai dapat diterima kembali bekerja di perusahaan. Mereka menjadi kurang mampu melihat kemungkinan lain untuk bekerja di luar perusahaan tambang. Kondisi ini mengharuskan perusahaan untuk dapat menerima mereka bekerja di proyek pertambangan migas. Menurut Rahman dkk. (2011:9) keberadaan perusahaan tambang termasuk migas akan berakhir di saat sumber daya tersebur habis. Sebagai bentuk tanggung jawab sosial perusahaan, perlu upaya untuk menghilangkan ketergantungan ekonomi masyarakat dan ekonomi lokal terhadap keberadaan sumber daya alam yang tidak terbarui.

Fenomena perkembangan CSR semakin menguat di era teknologi informasi dan komunikasi yang memungkinkan pengawasan atau kontrol 
publik terhadap aktivitas bisnis. Dengan mudah korporasi akan disoroti dan dikecam publik apabila melakukan bisnis dengan melanggar etika. Akibatnya, kepercayaan publik pada perusahaan pun akan tergerus atau bahkan hilang. Menurut Gray dkk (dalam Rusdianto, 2011:22) tumbuhnya kesadaran publik akan peran perusahaan ditengah masyarakat melahirkan sikap kritis karena menciptakan masalah sosial, kerusakan lingkungan, hak dan status tenaga kerja dan persoalan lainnya.

Menanggapi adanya kesadaran publik tentang kewajiban perusahaan, kegiatan public relation diarahkan untuk mempengaruhi pendapat, sikap, sifat dan tingkah laku publik. Sebagai bagian dari masyarakat, public relations harus selalu mengutamakan kepentingan publik, menggunakan moral atau hal baik, guna terpeliharanya komunikasi yang menyenangkan di masyarakat. Komunikasi didasarkan atas strategi dan teknik berinteraksi yang mengarah pada terciptanya suatu keadaan yang harmonis antara perusahaan dan masyarakatnya (Putra, 2015:74).

Perusahaan yang ingin mendapatkan kepercayaan dan legitimasi melalui kegiatan CSR perlu memiliki kapasitas untuk berkomunikasi dengan para pemangku kepentingan secara efektif. Strategi CSR yang terkuat pun akan berkurang jika perusahaan tidak memasukkan komponen komunikasi yang jelas (Rusdianto:19). Menyadari tentang pentingnya komunikasi sebagai upaya merespons tuntutan masyarakat, Exxon Mobil menggulirkan program CSR yang sesuai aspirasi dan kebutuhan mereka dengan jalan berwirausaha. Kehadiran program CSR ini bertujuan untuk memberikan informasi dan penyadaran tentang kesempatan bagi para pemuda untuk memperoleh penghasilan dengan jalan wirausaha tanpa menggantungkan diri pada perusahaan. Program ini diberi nama Taruna Bangga Usaha (Tangguh). Penelitian tentang CSR-pemberdayaan memang telah banyak dilakukan, namun penelitian ini mengkaji dari sudut pandang yang berbeda, yakni menganalisis lebih jauh tentang bagaimana model komunikasi program CSR untuk mencapai tujuan pemberdayaan wirausaha muda. 


\section{Metode Penelitian}

Penelitian ini menggunakan metode kualitatif dengan pendekatan deskriptif. Menurut Muhammad Natsir (1983:63) tujuan penelitian deskriptif adalah untuk membuat deskripsi, gambaran secara sistematis, aktual dan akurat mengenai fakta-fakta, sifat serta hubungan-hubungan antar fenomena yang diteliti. Penelitian ini diadakan di Desa Gayam, Kecamatan Gayam, Kabupaten Bojonegoro, Provinsi Jawa Timur pada tahun 2013. Dipilihnya lokasi ini karena Desa Gayam merupakan komunitas dampingan program CSR Tangguh Exxon Mobil yang berdekatan (kawasan ring satu operasi perusahaan) sehingga desa ini merasakan dampak dari operasi perusahaan secara langsung. Penelitian ini menggunakan teknik purposif dengan mengambil beberapa informan tertentu (key informan) sebagai subjek penelitian yang dianggap mampu mewakili stakeholder dalam program tersebut. Informan dalam penelitian ini yaitu tim pendamping Mercy Corps, para pemuda, staf departemen CSR Exxon Mobil, Dinas Koperasi, dan Pemerintah Desa.

Untuk memperoleh data yang valid dan dapat dipertanggungjawabkan, penelitian ini menggunakan teknik pemeriksaan keabsahan data dengan tehnik triangulasi. Menurut Moleong (2011:174) triangulasi adalah teknik pemeriksaan keabsahan data yang memanfaatkan sesuatu yang lain di luar data itu untuk keperluan pengecekan atau sebagai pembanding terhadap data itu. Melalui triangulasi, peneliti telah melakukan crosscheck data hasil wawancara dari berbagai informan staf departemen CSR perusahaan, mercy corps dan pemuda sehingga diperoleh jawaban wawancara yang dianggap benar.

\section{Profil Program Corporate Social Responsibility (CSR) Exxon Mobil}

Exxon Mobil merupakan korporasi besar yang berasal dari Amerika Serikat. Bidang usahanya meliputi energi dan petrokimia. Afiliasi Exxon Mobil telah beroperasi di Indonesia selama lebih dari 100 tahun. 
Pada tahun 1998 kantor pemasarannya dibuka di Indonesia untuk pertama kalinya, setelah itu berbagai pencapaiannya semakin menaikkan eksistensi Exxon di Indonesia.

Masuknya Exxon dalam pengelolaan Blok Cepu secara resmi bermula dari Kontrak Kerja Sama (KKS) Cepu yang ditandatangani pada 17 September 2005. KKS ini melibatkan dua anak perusahaan Exxon Mobil, yaitu Mobil Cepu Ltd (MCL), Ampolex (Cepu) Pte. Ltd., satu anak perusahaan Pertamina, yakni Pertamina EP Cepu, dan empat Badan Usaha Milik Daerah (BUMD) sebagaimana disyaratkan dalam KKS tersebut (www.exxonmobil.co.id) Perusahaan Exxon Mobil melaksanakan program CSR berfokus pada tiga pilar, yaitu pendidikan, kesehatan, dan pengembangan ekonomi. Sebagai gambaran tentang implementasi program CSR Exxon Mobil, berikut ini ditampilkan data komposisi program di Desa Gayam. (1) Program sektor pendidikan yang meliputi mobil perpustakaan keliling, peningkatan kualitas perpustakaan daerah. (2) Program sektor kesehatan yang meliputi peningkatan kapasitas bidan, program air bersih dan sanitasi berbasis masyarakat, penanggulangan demamberdarah, poliklinikkeliling dan pemberian makanan tambahan.(3) Program sektor lingkungan yang meliputi program pelestarian lingkungan hidup. (4) Program sektor ekonomi yang meliputi pembangunan dan perbaikan infrastruktur publik, pengembangan agroindustri ternak dan budidaya tanaman, program akses kredit usaha untuk perempuan miskin, pengembangan kewirausahaan perempuan melalui teknologi inovasi, program taruna bangga usaha, program pelatihan keterampilan industri dan program sukarelawan karyawan perusahaan.

Namun, penelitian ini difokuskan pada sektor ekonomi saja, yaitu program Tangguh yang menurut peneliti merupakan best practices implementasi CSR. Hal ini karena pelaksanaan program Tangguh telah menumbuhkan kemandirian sosial ekonomi dan kepercayaan masyarakat terhadap perusahaan. Program CSR di sektor yang lain seperti pendidikan, 
kesehatan dan lingkungan belum ada yang mengarah pada peningkatan kemandirian. Program masih dominan dalam bentuk fisik dan terfokus pada pembangunan fasilitas sosial dan fasilitas umum.

Sejak Mei 2012, program Tangguh melibatkan secara aktif para pemuda untuk memulai usaha, dan meningkatkan partisipasi mereka dalam kegiatan di masyarakat. Tujuan dari program Tangguh adalah memberdayakan potensi ekonomi lokal di Desa Gayam Kecamatan Gayam Kabupaten Bojonegoro melalui peningkatan kapasitas pemuda setempat agar mampu menjadi produktif secara ekonomi serta mampu bertindak sebagai pemimpin perubahan positif di masyarakat.

\section{Model Komunikasi Partisipatif Menurut Paulo Freire}

Model komunikasi partisipatif secara formal pertama kali diperkenalkan oleh Paulo Freire, seorang ahli pedagogi dari Brazil pada akhir tahun 1960-an dan 1970-an. Model ini berkaitan erat dengan akses dan pendekatan hak manusia untuk pembangunan. Model ini secara eksplisit menegaskan bahwa partisipasi orang dalam komunikasi sangat penting untuk keberhasilan proyek yang diberikan. Upaya untuk mendokumentasikan proyek komunikasi partisipatif telah banyak dilakukan di Amerika Latin, Afrika dan Asia (Versaes, 2008:38). Meskipun teori komunikasi dialogis Freire didasarkan pada dialog kelompok daripada media massa, namun ada pengertian bahwa teori ini dapat diterapkan pada hampir semua aspek komunikasi manusia dengan cara yang benarbenar partisipatif (Versaes, 1996:73).

Komunikasi partisipasi memegang peranan penting dalam pembangunan daerah dengan titik fokus pada keterlibatan aktif masyarakat dalam setiap tahapan pembangunan. Hal ini dibuktikan dalam penelitian (disertasi) oleh Ketan S. Chitnis tahun 2005 dengan berjudul "Communication for Empowerment and Participatory Development: a Social Model of Health in Jamkhed India". Hasil penelitian menunjukkan bahwa komunikasi par- 
tisipatif dengan menggunakan prinsip Freirean dapat berkontribusi untuk memberdayakan orang miskin jika dilakukan dengan waktu jangka panjang.

Makna komunikasi dalam paradigma komunikasi pembangunan partisipatif adalah pergeseran pesan dengan fokus menginformasikan dan membujuk perubahan perilaku kepada penyediaan fasilitas untuk masyarakat dan pemerintah dalam menentukan masalah bersama. Dalam hal ini terjadi perubahan pendekatan top down, linear dan searah menuju pendekatan horizontal, interaktif dan dialogis (buttom-up). Komunikasi lebih dimanfaatkan untuk membantu proses balajar melalui pertukaran informasi secara transaksional. Masyarakat diharapkan mampu mengidentifikasi kebutuhan akan informasi dan komunikasi sehingga memungkinkan untuk mengurangi terjadinya konflik di dalam kelompok, komunitas, dan pemangku kepentingan lainnya (Muchtra, 2016:23).

Kehadiran program Tangguh diharapkan dapat berkontribusi untuk kemajuan pembangunan daerah. Partisipasi dalam komunikasi mendorong adanya keterlibatan berbagai pihak yang berkepentingan untuk membangun jaringan kerja sama dalam mencapai tujuan bersama. Mereka yang berkepentingan dan berkontribusi untuk membantu pelaksanaan program adalah perusahaan, Mercy Corps, pemerintah Desa, Kecamatan dan Kabupaten, Disnakertransos, Dinas Koperasi dan UKM, Karang Taruna, tokoh masyarakat, para pemuda sebagai calon penerima manfaat program dan masyarakat.

Gagasan komunikasi partisipatif menekankan pentingnya identitas budaya komunitas lokal, dan demokratisasi dan partisipasi di semua tingkatan baik internasional, nasional, lokal dan individual. Freire (1983) menyatakan hak semua orang untuk berbicara baik secara individu ataupun kolektif. Untuk berbagi informasi, pengetahuan, kepercayaan, dan komitmen dalam proyek-proyek pembangunan, partisipasi sangat penting dalam proses pengambilan keputusan (Versaes, 1996:75).

Program Tangguh menyediakan layanan informasi bisnis, berbagai 
pengetahuan dan pengalaman pemuda untuk terlibat dalam perencanaan dan pelaksanaan program CSR dan proyek pembangunan. Berbagai informasi yang bersumber dari pemuda itu kemudian dirumuskan dalam pengembangan potensi ekonomi dan sumber daya untuk menciptakan peluang usaha di sekitar wilayah industri. Program wirausaha dipilih sebagai strategi mengatasi kesenjangan sosial dan persoalan kemiskinan untuk memperoleh kesejahteraan bersama perusahaan. Program Tangguh diarahkan guna memenuhi kebutuhan masyarakat khususnya kalangan pemuda tentang pelayanan bisnis, akses informasi, penyediaan barang dan jasa, bantuan modal untuk mempersiapkan mereka berwirausaha.

Dalam program Tangguh, komunikasi partisipatif dipraktikkan dengan upaya melibatkan partisipasi pemuda, menghilangkan diskriminasi gender dan mengajak mereka yang sering terabaikan dalam proses pengambilan keputusan. Dengan kata lain, proses komunikasi partisipatif dilakukan untuk membantu mewujudkan prinsip-prinsip pemberdayaan, pemerataan dan keadilan sosial.

Landasan pemberdayaan program Tangguh ditunjukkan dengan keberpihakan untuk melibatkan partisipasi pemuda yang belum berdaya dalam mengakses lapangan kerja di sekitar wilayah operasi industri migas. Oleh karenanya dalam proses rekrutmen program Tangguh, target penerima manfaat program adalah pemuda dan 50\% dari total penerima manfaat adalah perempuan. Program ini memberikan perhatian para pemuda yang tidak memiliki tingkat pendidikan setara SMU dan pemuda yang tidak bersekolah dan belum mendapatkan pekerjaan untuk dapat mengikuti pelatihan wirausaha.

Pada dasarnya setiap manusia memiliki kemampuan untuk mengaktualisasikan potenisnya jika diposisikan sebagai subyek perubahan. Menurut Freire (2006:xxxvi) fitrah manusia secara ontologis manusia pada hakikatnya dipanggil menjadi subyek yang harus mengerjakan dan mengubah dunia, dan karenanya selalu bergerak menuju kemungkinan- 
kemungkinan yang senantiasa baru, membuat kehidupan ini senantiasa menjadi makin penuh dan kaya, baik secara individul atau kelompok.

Komunikasi partisipatif memiliki prinsip berupa pelaksanaan dialog sebagai bentuk penghargaan terhadap hak asasi manusia. Program CSR Tangguh menunjukkan pelaksanaan dialog sebagai wujud komunikasi partisipatif. Dalam pertemuan-pertemuan antara mitra pengelola CSR dengan masyarakat diadakan berbagai diskusi, pelatihan, kompetisi rencana usaha, hingga pemberian bantuan usaha, pendirian dan pengembangan usaha. Semua itu dilakukan atas dasar kebutuhan yang dirasakan masyarakat sebagai tanggapan terhadap potensi di sekitar mereka. Masyarakat memiliki kesempatan menyampaikan ide, merencanakan usaha dan menikmati penghasilan yang diperoleh setelah usaha berlangsung. Program ini merupakan bentuk penghargaan kepada SDM lokal untuk belajar dan berkarir menjadi wirausaha muda di wilayah industri migas.

\section{Model Komunikasi Partisipatif Program CSR Tangguh}

Dalam menjalankan komunikasi tanggung jawab sosial perusahaan (CSR) dikategorikan menjadi dua hal, yaitu tentang masalah dan keterlibatan perusahaan dalam penyelesaian masalah. Masalah yang dialami masyarakat yang hendak diselesaikan, berarti perusahaan menekankan pentingnya masalah tersebut diselesaikan, dan perusahaan tidak memiliki vested self-interest atas penyelesaian masalah itu. Sedangkan keterlibatan perusahaan dalam penyelesaian masalah, berarti perusahaan menekankan komitmen penyelesaian, dampak keterlibatan perusahaan, mengapa perusahaan melibatkan diri, kedekatan masalah dengan bisnis perusahaan (Jalal, 2010 dalam Rusdianto, 2013:48). Munculnya masalah sosial yang dirasakan masyarakat juga menjadi bagian dari masalah perusahaan untuk mendapatkan simpati dan citra positif sebagai license social dan keberlanjutan bisnis perusahaan. 
Secara operasional, upaya perusahaan untuk penyelesaian masalah dilakukan dengan komunikasi dua arah dengan melibatkan partisipasi masyarakat terutama kalangan pemuda sebagai sumber informasi. Melalui komunikasi dua arah perusahaan dapat terlibat dalam komunikasi dengan para pemangku kepentingan, mendengarkan dan mengubah tindakan mereka sebagai hasil dari interaksi yang terjadi, sehingga dapat tercipta hubungan yang harmonis antara perusahaan dengan berbagai pemangku kepentingan (Rusdianto, 2013:31).

Dalam menjalankan komunikasi dengan komunitas, perusahaan akan melihat terlebih dahulu seperti apa kebutuhan masyarakat (dalam hal ini para pemudanya), apa persoalannya, apa potensi yang mereka miliki. Lalu setelah dikaji baru diputuskan bagaimana merumuskan program CSR yang baik dan tepat. Untuk memperoleh informasi dan data yang dibutuhkan maka proses komunikasi dilakukan dengan dialog yang melibatkan partisipasi pemuda sebagai subyek aktif dalam menyampaikan aspirasi, problem sosial dan sumber daya yang dimiliki. Dengan komunikasi dialogis diperoleh gambaran kapasitas dan kesungguhan pemuda untuk mendayagunakan potensinya agar siap menjadi wirausaha dan bersama hidup berdampingan dengan perusahaan. Berikut ini dipaparkan model komunikasi dua arah yang menekankan prinsip partisipatif dan dialog dalam perumusan dan pelaksanaan program CSR dapat dilihat pada gambar di bawah ini: 


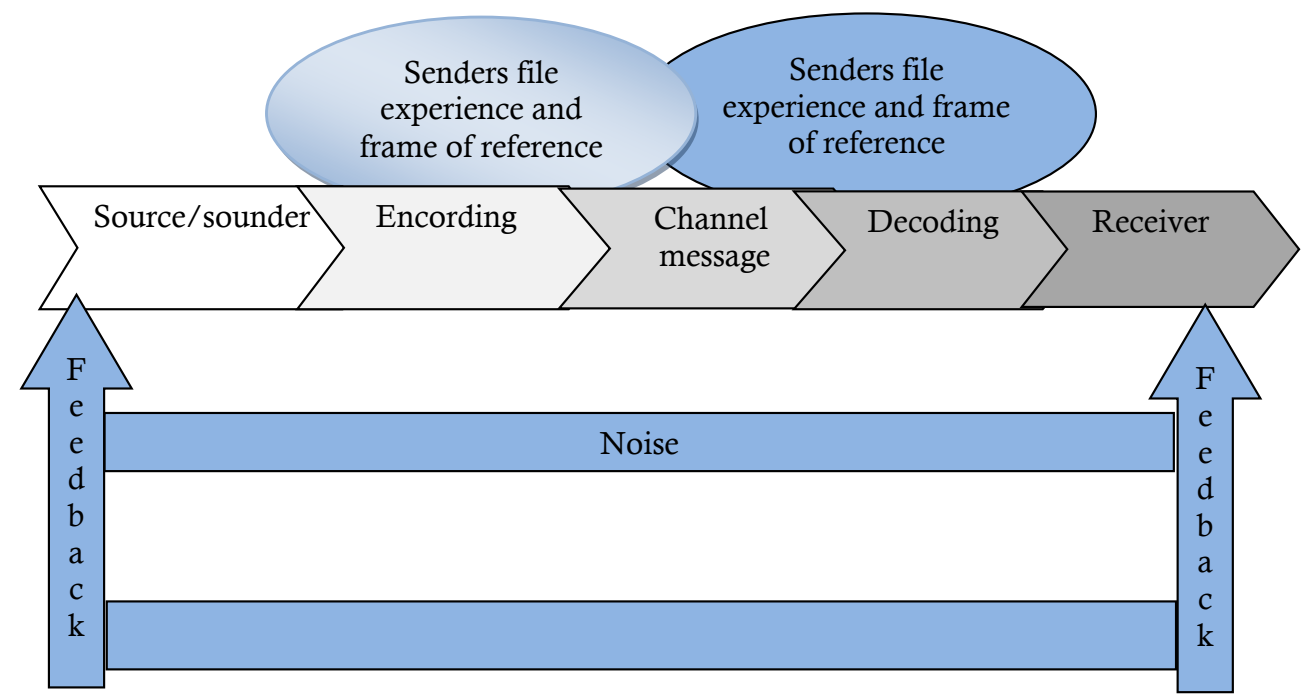

Gambar1. Model Komunikasi CSR Dua Arah (Rahman, 2009:72-7:)

Berdasarkan model komunikasi di atas dapat dipahami bahwa melalui mekanisme komunikasi, alur penyampaian pesan dilakukan oleh perusahaan yang bertindak sebagai komunikator dalam pesan program CSR, sedangkan para pemuda menjadi sumber informasi. Adapun saluran dan jaringan komunikasi yang telah dibangun perusahaan adalah teknologi informasi yang menghubungkan para pemuda dengan program Mercy Corps-Global Citizen Corps (GCC). Program ini merupakan sarana untuk saling berbagi informasi dan pengalaman antar pemuda. Kegiatan ini dilakukan melalui video conference dengan cara interaksi tatap muka dan berbicara secara langsung dengan pemuda program GCC di Jakarta. Di dalam video conference ini para pemuda berbagi cerita sukses dan pengalaman tentang kehidupan di daerah masing masing.

Selanjutnya, untuk meningkatkan pelayanan informasi perusahaan mendirikan business centre di Desa Gayam. Layanan utama business centre ini adalah penyediaan informasi tentang bagaimana memulai usaha baru, apa saja yang harus dipersiapkan dan bagaimana mengakses modal usaha. Business center telah memiliki kantor sendiri dan menyediakan buku-buku tentang kewirausahaan dan komputer. Untuk mengetahui 
perkembangan dan kendala permasalahan usaha pemuda, business centre sering kali menjadi rujukan untuk melakukan monitoring dan evaluasi.

Adapun proses pengkodean dan penerjemahan pesan dilakukan oleh masing-masing partisipan komunikasi untuk mencapai kesepahaman. Kesepahaman yang lahir di setiap partisipan komunikasi akan dipengaruhi oleh latar belakang dan pengalaman (field of experience) dan tingkat pendidikan (frame of reference) masing-masing. Semakin dekat relasi kedua faktor ini maka semakin tinggi pula probabilitas komunikasi efektif akan tercipta. Program CSR Tangguh memiliki keunikan karena mengedepankan pengetahuan dan keterampilan lokal dengan melihat peluang bisnis di sekitar wilayah industri migas. Para pemuda menggali informasi, mendayagunakan aset perekonomian masyarakat di tengah aktivitas perekomian industri yang dalam kesehariannya membutuhkan barang dan jasa untuk karyawan perusahaan dan masyarakat setempat.

Kesepahaman yang muncul diantara partisipan komunikasi akan mendorong terciptanya tindakan dua arah (reciprocal action), setiap partisipan memiliki kesempatan yang sama untuk saling memberikan respon dan umpan balik. Di sini terjadi komunikasi dua arah. Tidak dikenal adanya pembedaan komunikator dan komunikan mengingat masing-masing pihak memainkan kedua peran tersebut dalam waktu yang bersamaan.

Komunikasi dalam Program CSR Tangguh berusaha membangun kesetaraan untuk mempertamukan antara kepentingan perusahaan dan tuntutan kebutuhan para pemuda. Para pemuda sebagai pelaku program CSR Tangguh diberikan kewenangan dan kesempatan yang sama untuk menyampaikan pendapat dan berdialog dengan perusahaan. Mereka menentukan pilihannya sendiri tentang jenis usaha apa yang hendak dijalani sesuai minat dan bakat yang dimiliki. Para pemuda dijadikan sumber informasi dan pelaku utama yang dapat menentukan pilihan masa depannya dan perusahaan menjadi saluran komunikasi untuk merespons 
dan memberi umpan balik atas tuntutan kebutuhan mereka. Dengan kata lain, terjadi proses komunikasi secara dialogis sebagai landasan komunikasi partisipatif.

Komunikasi partisipatif dalam membangun kapasitas masyarakat menekankan pada partisipasi dalam pengambilan keputusan melalui proses dialog. Pemaknaan dialog memungkinkan setiap orang yang terlibat memperoleh pengakuan hak dan kesetararaan antar komunikator dalam berbicara dan menyampaikan gagasannya. Partisipasi dalam komunikasi dialog diharapkan mampu menumbuhkan kesadaran kritis tentang persoalan yang dirasakan, mencari solusi dan upaya pemecahannya. Hanya dialog yang menuntut adanya pemikiran kritis, yang mampu melahirkan pemikiran kritis. Tanpa dialog tidak akan ada komunikasi, dan tanpa ada komunikasi tidak akan mungkin ada pendidikan yang benar (Freire, 2016:84).

Dialog menuntut adanya keyakinan yang mendalam terhadap diri manusia, keyakinan terhadap kemampuan manusia untuk membuat dan membuat kembali, untuk mencipta dan mencipta kembali, keyakinan pada fitrahnya untuk menjadi manusia seutuhnya (yang bukan hak istimewa kelompok elite, tetapi hak kelahiran semua manusia) (Freire, 2016:81). Freire percaya bahwa individu memiliki kapasitas untuk refleksi, konsep, berpikir kritis, membuat keputusan, untuk perencanaan dan perubahan sosial. Itu bukan hanya kesadaran, namun itu penting, hubungannya dengan program transformasi sosial, di mana kesadaran dan tindakan kesadaran terhubung secara dialektis. Lebih lanjut, aksi dan refleksi terintegrasi secara organik. Ini adalah dialektika dan proses aksi dan refleksi emansipatif yang menjadi proses kesadaran kritis (Versaes, 1996:78).

Kesadaran kritis menurut Freire yaitu ketika dalam diri seseorang dapat dicapai dengan cara melihat ke dalam diri sendiri (looking inward) serta menggunakannya apa yang didengar, dilihat dan dialami untuk 
memahami apa yang sedang terjadi dalam kehidupannya. Seseorang menganalisis sendiri masalah yang dihadapinya, mengidentifikasi sebabsebabnya, menetapkan skala prioritasnya dan memperoleh pengetahuan baru darinya (Hikmat, 2001:42). Oleh karenanya kesadaran kritis menekankan pada kemampuan masyarakat untuk mampu membaca realitas dan masalah sosial didalamnya sehingga akan memicu tindakan perubahan sosial untuk mengubahnya.

\section{Praktik Pemberdayaan Wirausaha Muda}

Program CSR Tangguh di Desa Gayam dirumuskan bukan sekadar untuk merespons keinginan dan tuntutan masyarakat setempat, melainkan juga untuk mengalisis lebih jauh permasalahan dan potensi setempat guna menjawab kebutuhan para pemudanya sebagai calon wirausaha di sekitar wilayah industri. Peranan fasilitator adalah membantu masyarakat mendefinisikan kebutuhan mereka sendiri. Bantuan itu dapat berupa keahlian yang diperlukan oleh masyarakat dan diberikan melalui fasilitasi proses, tetapi bantuan itu bukanlah pengambilalihan tanggung jawab dari masyarakat dalam mendefinisikan kebutuhan mereka sendiri. Dengan demikian, tidak ada penyingkiran hak masyarakat untuk mengontrol nasibnya sendiri (Jim Ife, 2008:157).

Menurut Soetomo (2011:70) pemberdayaan adalah sebuah pendekatan yang memberikan kesempatan, wewenang yang lebih besar kepada masyarakat terutama masyarakat lokal untuk mengelola proses pembangunan. Kewenangan tersebut meliputi keseluruhan proses pembangunan sejak identifkasi masalah dan kebutuhan, perencanaan, pelaksanaan, evaluasi dan menarik manfaat. Sudah tentu agar masyarakat lokal dapat menjalankan wewenang tersebut dengan baik diperlukan kapasitas untuk melakukannya. Oleh sebab itu, unsur utama dari proses pemberdayaan masyarakat, selain pemberian wewenang, adalah juga peningkatan kapasitas masyarakat. 
Pada tahap perencanaan, perusahaan mengadakan pelatihan wirausaha yang dimulai pada bulan Oktober 2012. Selama pelatihan kewirausahaan, para pemuda diajarkan tentang bagaimana menjadi seorang wirausaha yang sukses dan berkelanjutan sebagai pilihan karir mereka. Adapun materi yang diberikan dalam pelatihan wirausaha pemuda antara lain; dasar-dasar kewirausahaan, analisis peluang pengembangan usaha, etika bisnis, pembuatan business plan dan lain-lain. Pelatihan ini diikuti oleh para pemuda yang ingin dan berencana menjadi wirausaha atau tidak memiliki usaha dan mereka yang telah memiliki usaha kecil dan menengah yang telah berjalan.

Setelah melalui rangkaian pelatihan wirausaha, para pemuda diminta untuk mengajukan perencanaan bisnis (business plan) dan berkompetisi untuk mendapatkan bantuan usaha. Tepatnya pada bulan Desember 2012, kompetisi business plan diselenggarakan di Hotel Griya Dharma Kusuma Bojonegoro. Para pemuda yang telah menyerahkan business plan-nya selanjutnya mempresentasikan rencana usaha mereka di hadapan para dewan juri yang terdiri dari perwakilan Exxon Mobil, Mercy Corps dan pengusaha lokal Bojonegoro. Selama proses presentasi, para dewan juri memberikan pertanyaan untuk menguji kelayakan pengajuan usaha mereka. Sedangkan peserta diberikan kesempatan untuk mempertahankan pendapatnya tentang peluang pengembangan dalam rencana usahanya.

Setelah melewati penilaian, terpilih 9 usaha sebagai pemenang dari kompetisi business plan tersebut. Para pemenang kompetisi ini selanjutnya mendapatkan bantuan peralatan usaha untuk memulai usahanya sesuai dengan business plan masing-masing. Pemilihan jenis usaha juga disesuaikan peluang bisnis disekitar wilayah operasi perusahaan agar usaha mereka dapat berkembang secara mandiri dan berkelanjutan. Usaha yang diajukan dalam kompetisi ini antara lain baby shop collection, salon kecantikan, laundry, toko kelontong, kuliner, plays station, pijat 
tradisional, aneka gorengan dan minuman, aneka roti, peternakan domba, peternakan ayam, lukisan dan lain-lain.

Berbagai pelatihan dan kompetisi business plan ini dimaksudkan untuk meningkatkan kualitas pelayanan, meningkatkan kapasitas sumber daya manusia dari para aktor yang terlibat dalam program CSR tersebut. Para pemuda yang memenangi kompetisi business plan mendapatkan bantuan usaha. Hal ini bertujuan untuk membantu para pemuda mempersiapkan diri menjadi wirausaha dengan memulai usaha mereka. Bantuan yang diberikan tidak berupa uang, tetapi perlengkapan dan fasilitas yang dibutuhkan untuk memulai usaha. Hal ini dilakukan agar bantuan dapat segera dimanfaatkan untuk memulai usaha dan mencegah penyalahgunaan bantuan.

Pada tahap evaluasi diketahuibahwa para pemuda rata-rata memulai usaha pada bulan Februari 2013. Berbagai jenis usaha yang dijalankan pemuda turut membantu masyarakat dalam pemenuhan kebutuhan barang dan jasa ditengah keramaian aktivitas operasi perusahaan. Dengan berwirausaha secara mandiri, para pemuda akan melupakan tentang profesi pekerjaan perusahaan yang sebelumnya menjadi kebanggaan dan diminati. Membuka usaha sendiri dan berkelanjutan dalam jangka panjang adalah jaminan sosial untuk tetap melanjutkan pekerjaan meskipun nantinya perusahaan akan pergi meninggalkan masyarakat jika sumber daya alam migas telah habis.

\section{Manfaat Program (Multyplier Effect) dari Perspektif Komunikasi}

Menurut Rahman (2009:71) kualitas program CSR yang baik haruslah diimbangi oleh komunikasi yang baik. Pada tahap awal komunikasi partisipatif yang dikaji adalah bagaimana program Tangguh menumbuhkan ide sebagai rujukan dalam merumuskan program. Inisiatif program CSR Tangguh berangkat dari hasil penelitian. Exxon Mobil yang bekerjasama dengan Lembaga Swadaya Masyarakat (LSM) Mercy Corps. 
Kemitraan dimaksudkan untuk mempersiapkan sumberdaya manusia yang dapat membantu perusahaan dalam menjalankan program. Program CSR Tangguh adalah hasil kolaborasi antara Exxon Mobil dengan Mercy Corps. Kemitraan perusahaan dengan Mercy Corps dimaksudkan untuk mempersiapkan sumberdaya manusia yang dapat membantu perusahaan dalam menjalankan program.Menurut Hadi(2011:137) penyiapan sumber daya manusia yang handal merupakan tahapan penting dan menentukan tingkat keberhasilan pelaksanaan CSR. Implementasi kemitraan CSR menjadi tanggung jawab kedua belah pihak.

Kemitraan yang dijalankan perusahaan menggunakan mixe type. Tipe kombinasi sendiri yaitu Mercy Corps merancangprogam CSR sesuai dengan arahan dan keinginan perusahaan dan masyarakat, kemudian untuk operasinya melibatkan berbagai stakeholder yang terkait seperti pemerintah, tokoh masyarakat dan masyarakat sebagai calon penerima manfaat program. Pelibatan stakeholder selain untuk meringankan beban kerja perusahaan, juga berfungsi untuk menstimulus stakeholder agar dapat terlibat dan mendukung progam CSR guna terciptanya kerjasama yang saling menguntungkan.

Gagasan tentang program CSR Tangguh berangkat dari proses assesment tentang kondisi sosial ekonomi masyarakat di sekitar operasi perusahaan. Hasilnya menunjukkan bahwa tingkat pendidikan SDM usia produktif masyarakat setempat memang belum memenuhi tuntutan kebutuhan kerja di proyek migas. Masyarakat sekitar perusahaan kebanyakan memiliki tingkat pendidikan SMP. Jadi, ada kesenjangan yang cukup lebar antara spesifikasi dan kualitas SDM setempat dengan tuntutan kerja perusahaan.

Berangkat dari hal tersebut, program Tangguh diarahkan untuk mengatasi persoalan kesenjangan sosial dengan jalan wirausaha tanpa bergantung pada perusahaan. Menurut Abdullah (2015:31) dalam perspektif ilmu komunikasi, apa yang dilakukan oleh korporasi untuk 
melaksanakan tanggung jawab sosialnya dapat mencapai hasil yang berlipat ganda (multyplier effects). Ini terlihat pada indikator kapasitas perusahaan dalam mengatasi masalah sosial tersebut, dan disisi lain keberadaan korporasi semakin dirasakan manfaatnya oleh komunitas. Peran korporasi dalam memajukan komunitas dapat dilihat pada gambar di bawah:

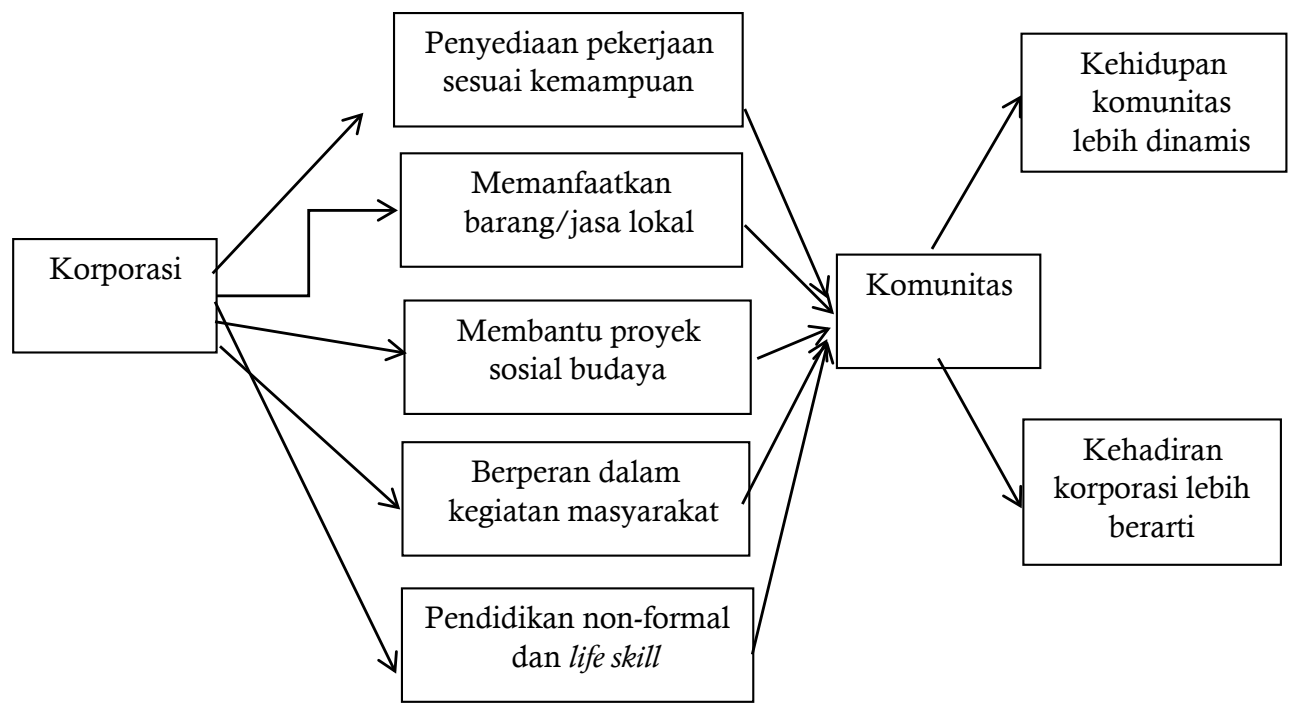

Gambar 2. Peran Korporasi dalam Memajukan Komunitas dengan Multyplier Effects (Abdullah, 2015:31-33)

Dari penjelasan gambar di atas diketahui bahwa korporasi berusaha membangun relasi yang lebih bermakna lagi melalui kegiatan atau upayaupaya berikut: 1) Desain Program CSR Tangguh disesuaikan dengan minat dan kapasitas pemuda. Adapun pemilihan jenis usaha disesuaikan dengan peluang bisnis disekitar wilayah operasi perusahaan agar usaha mereka dapat berkembang secara mandiri dan berkelanjutan. 2) Program CSR Tangguh telah melahirkan wirausaha lokal dengan menyediakan barang dan jasa untuk memenuhi kebutuhan baik untuk karyawan perusahaan ataupun masyarakat setempat. Daftar nama pemilik dan jenis usaha Tangguh yang telah berdiri di Desa Gayam dapat dilihat pada Tabel di bawah: 
Tabel 1. Daftar nama pemilik dan jenis usaha Tangguh

\begin{tabular}{cll}
\hline No. & \multicolumn{1}{c}{ Jenis Usaha } & \multicolumn{1}{c}{ Pemilik } \\
\hline 1 & Pijit tradisional & Agus Malik \\
\hline 2 & Warung bakso dan mi ayam & Atul \\
\hline 3 & $\begin{array}{l}\text { Warung sembako dan aneka gorengan } \\
\text { minuman }\end{array}$ & Diana \\
\hline 4 & Jasa Laundry & Ida Rukmana \\
\hline 5 & Rental Play Station & Sutiona \\
\hline 6 & Warung Sembako & Puji Utami \\
\hline 7 & Salon Kecantikan & Tanti \\
\hline 8 & Peternakan domba & Ji'in \\
\hline 9 & Baby Shop collection & Santosa \\
\hline
\end{tabular}

Usaha-usaha yang dilakukan oleh pemuda tersebut, telah memberikan dampak ekonomi yang positif kepada masyarakat dengan terciptanya lapangan kerja baru yang menyerap tenaga kerja di Desa Gayam, Kecamatan Gayam. Sembilan usaha yang saat ini tengah berjalan telah mampu menyerap 12 pemuda dan orang dewasa untuk terlibat menjalankan usaha, baik sebagai pemilik usaha maupun pekerja.

Dari sisi budaya, program Tangguh menumbuhkan jaringan kerjasama, sikap saling peduli dan menghormati, serta tumbuhnya kepercayaan masyarakat terhadap perusahaan. Dari aspek sosial, penghargaan terhadap SDM lokal ini dapat meningkatkan hubungan sosial antara perusahaan dan masyarakat di sekitanya karena masyarakat merasa diperhitungkan. Sehingga partisipasi aktif dalam kegiatan kemasyarakatan dipelopori oleh kalangan pemuda sebagai agen perubahan dalam memajukan kehidupan masyarakat.

Untuk meningkatkan kapasitas pemuda, program CSR Tangguh diawali assesment tentang permasalahan dan potensi ekonomi, kemudian memberikan rangkaian pelatihan wirausaha, kompetisi business plan hingga bantuan usaha. 


\section{Simpulan}

Keterampilan melakukan komunikasi partisipatif bagi perusahaan yang melaksanakan program CSR-pemberdayaan mutlak diperlukan. Komunikasi yang perlu dijalankan adalah komunikasi yang memberdayakan dengan mengakui kemampuan masyarakat untuk pemecahan masalah dan aktualisasi potensi diri. Ini merupakan sebuah model komunikasi yang menempatkan masyarakat sebagai komunikator dan subyek utama yang aspirasi dan kebutuhannya harus didengarkan. Komunikasi partisipatif program CSR Tangguh berperan penting dalam upaya memberdayakan wirausaha muda sebagai pilihan karier dan bersaing dalam pasar tenaga kerja di wilayah proyek industri migas. Hal ini tampak dengan meningkatnya kemandirian ekonomi dan akses lapangan pekerjaan baru yang memicu tumbuhnya pengusaha lokal pemasok barang dan jasa untuk memenuhi kebutuhan masyarakat. $\mathrm{Hal}$ ini diharapkan mampu menjaga kesinambungan kehidupan masyarakat di masa mendatang, terutama jika perusahaan telah meninggalkan lokasi.

\section{Daftar Pustaka}

Abdullah, Ma'ruf. 2015. Manajemen Komunikasi Korporasi. Yogyakarta: Aswaja Pressindo.

Bowen, Howard R. 1953. Social Responsibilities of the Businessman. New York: Harper \& Brother.

Chitnis, S. Ketan. 2005. Communication for Empowerment and Participatory Development: a Social Model of Health in Jamkhed India. Kanada: Ohio University

Efendi, Asep dan Emir Wikacana, Nurdizal M. Rahman. 2011. Panduan Lengkap Perencanaan CSR. Jakarta: Penebar Swadaya

Freire, Paulo. 2016. Pendidikan Kaum Tertindas. Terj. Utomo Danandjaya dkk.Jakarta: Pustaka LP3ES.

Hadi, Nor. 2011. Corporate Social Responsibility. Yogyakarta: Graha Ilmu. 
Hasan, Saipullah dan Devy Andriany. 2014. Pengantar CSR, Sejarah, Pengertian dan Praksis. Yogyakarta: Pustaka Pelajar.

Hikmat, Harry. 2001. Strategi Pemberdayaan Masyarakat. Bandung: Humaniora Utama Press.

Ife, Jim dan Frank Tesoriero. 2008. Alternative Pengembangan Masyarakat di Era Globalisasi Community Development. Yogyakarta. Pustaka Pelajar.

Moelong, J. Lexy. 2012. Metode Penelitian Kualitatif. Bandung: PT Remaja Rosdakarya.

Muchtar, Karmila. "Penerapan Komunikasi Partisipatif Pada Pembangunan di Indoneisa". Jurnal Makna, Vol 1, Nomor 1, Maret 2016. Fakultas Ekologi Manusia. Institut Pertanian Bogor (IPB)

Muthuri, Judy N., and Victoria Gilbert. "An Institutional Analysis of Corporate Social Responsibility In Kenya". Journal of Business Ethic 2010.

Nazir, Moh. 1992. Metode Peneitian, Jakarta: Ghalia Indonesia

Putra, Dedi Kurnia Syah. 2015. Komunikasi CSR Politik, Membangun Reputasi, Etika, dan Estetika PR Politik. Jakarta: Prenadamedia Group. Rahman, Reza. 2009. Corporate Social Responsibility. Antara Teori dan Kenyataan. Yogyakarta: Media Pressindo.

Rusdianto, Ujang. 2013. CSR Communication A Framework for PR Practitioners. Yogyakarta: Graha Ilmu.

Servaes, Jan. 2008. Communication for Development and Social Change. India: Sage Publications

Shaw, HW. 2009. "Marxism, Business Ethics, and Corporate Social Responsibility". Journal of Business Ethics. 84:565-578.

Soetomo. 2011. Pemberdayaan Masyarakat Mungkinkah Muncul Antitesisnya? Yogyakarta: Pustaka Pelajar.

Suharto, Edi. CSR dan Comdev Investasi Kreatif Perusahaan di Era Globalisasi. Bandung: Alfabeta.

Susetiawan. 2012. Corporate Social Responsibility Komitmen untuk Pember- 
INJECT (Interdisciplinary Journal of Communication), Vol.3, No.1, Juni 2018: h. 59-82

dayaan Masyarakat. Yogyakarta: Azzagrafika

Undang-Undang No. 22 Tahun 2001 tentang Perusahaan Minyak dan Gas Bumi.

\section{Internet}

Servaes Jan. 1996. Partisipatory Communication (Research) From a Freiran Perspective. African e-Journals Project. Mighican State University Libraries http://digital.lib.msu.edu/projects/ africanjournals/ www.exxonmobil.co.id, 2010, Exxon Mobil Areas of Operations in Indonesia, http://www.exxonmobil.co.id/content/exxon-mobilareas-of-operations-in-indonesia di akses tanggal 1 Oktober 2014 